\title{
4 Text clustering and methods in the Book of Leinster
}

Most investigations of the Book of Leinster (hereafter LL) have used close reading, historical, and philological techniques to identify authors within LL (for instance, see Mac Gearailt 1993; Bhreathnach 2002; Mac Gearailt 1997-1998; Ó Lochlainn 1941-1942; Ó Lochlainn 1943-1944; Mac Eoin 1982: 113-114). While this has met with some success, the methods used are by their nature idiosyncratic and prone to individual scholarly opinion. One notable exception is Derick Thomson's paper The Poetry of Niall MacMhuirich which attempts to use statistical methods to attribute authorship of poems to Niall MacMhuirich (Thomson 1970). This paper will use methods of anonymous authorship attribution, which has been developed within the discipline of machine learning and statistical analysis to accomplish two goals: first, to demonstrate the means and methods of unsupervised machine learning techniques in early Irish literature and second, to discuss the implications of the application of this methodology to LL with a view towards a larger research project.

The paper will proceed in four stages. First, some scholarly literature concerning LL is reviewed. Second, the methods of data gathering, along with certain related problems, as well as the algorithms used in the analysis are commented upon. Third, the outcome of the analysis is summarised. Fourth, the paper concludes with an examination of the contribution the analysis makes to the debate surrounding the authorship of LL.

\section{The context of LL}

LL, next to Lebor na hUidre (hereafter, LU, Best and Bergin 1929), is one of the great monuments of Irish literary culture, which was written between 1151 to around 1201 (Schlüter 2010: 24; see also Duncan 2012: 45-56). Most of the manuscript is in the hand of Âed mac Crimthainn (usually cited as A); however, there are five other discernible hands: F, T1-4, M, U, and S (Duncan 2012; see also Schlüter 2010: 27). Overall, there are 164 texts, which have 189,472 words in total. The provenance of the manuscript is the subject of much debate. According to Schlüter, LL was the product of the monastery at Cloneagh in Leinster and it may have been moved to Núachongbáil for safety during the wars of the 12th century, 
where it gained its medieval name. In addition, it was probably written for the Loígis and celebrates their ancestor the Ulsterman Conall Cernach, which accounts for much of the Ulster material in an otherwise Leinster book (Schlüter 2010: 30-35; see also Duncan 2012: 45-49).

A modern diplomatic edition of the entire manuscript was produced by Best, Bergin, and others (Best et al. 1954-1983). Moreover, many of the texts found in the manuscript have been published separately as critical editions (for instance, see O'Rahilly 1967). Currently, the entirety of the LL diplomatic edition is available in TEI (TEI Consortium 2009) XML format at CELT. The CELT version of the diplomatic edition of LL is the basis for all work considered in this chapter.

In an attempt to ascribe authorship to scribes of the versions of Táin Bó Cúalnge, Cath Ruis na Ríg, and Mesca Ulad found in LL, Mac Gearailt breaks up Táin Bó Cúalnge into "regions", then performs some statistical analysis on the orthography and language of each region (Mac Gearailt 1993: 172-178). He concludes that scribes $\mathrm{A}$ and $\mathrm{T}$ intervened in the text and made their own contribution (Mac Gearailt 1993: 205). In a later study, Mac Gearailt (1997-1998: 405) attempts to date the Táin Bó Cúalnge by counting and cataloguing infixed pronoun usage and style and concludes that:

Finally, it may be noted that while non-historical infixed forms in the LL Tain can be assigned to the period when CRR-LL was composed, many others which conform fully to Olr. or Mid. Ir. rules are survivals from a much earlier stage of Recension II . . .

Mac Eoin (1982) discusses authorship in terms of unreliability of dating. In this he laments the situation but holds out hope that the separation of prose and poetry could assist in distinguishing between the original and any additions:

But how are we to judge the validity of attributions to poets who fall within the Middle Irish period? It is often assumed that ascriptions to Middle Irish poets in Middle Irish manuscripts like LU, LL, and Rawl. are reliable. Some would certainly seem trustworthy, but their reliability is not enhanced by ascriptions to Cormac macc Airt, Medb Lethderg, and Ailill Óluimm on the adjoining pages.

(Mac Eoin 1982: 124)

Ó Lochlainn (1941-1942) and (1943-1944) attempts to use textual sources to secure attribution of authorship to poems traditionally ascribed to Mac Coise. This is done by using various features of Middle Irish to date the poem and the date of Mac Coise's death in the early Irish annal to demonstrate that Mac Coise could not have written the poems under consideration. This position was re-evaluated by O'Leary (1999) who argued that there were three different people named Mac Coise whose poems can be securely ascribed: Airbertach mac Cosse Dobráin, Iorard mac Coisi, and mac Coisi (O’Leary 1999: 69-71). 
As the examples above show, with few exceptions the main method of modern scholarly authorship attribution uses stylistic dating and dating with reference to annals or other sources of textual evidence to assign or at least question the authorship attributions made by the scribes of various early Irish manuscripts.

With this in mind, the next step is to begin with the mechanics of how to use unsupervised machine learning techniques on early Irish literature using LL as an example.

\section{$2 \mathrm{LL}$ as a list of vectors}

While the foregoing has set the scene for the current state of the scholarly debate, this section will explore the various methods of data gathering and analysis. This section is by necessity highly technical in nature and will require close attention to the means by which a written text can be transformed into a mathematical object.

Many of the texts which appear in LL, (e.g. Lebor Gabála), also appear in other Irish manuscripts, which would suggest that other manuscript versions should also be included in the analysis. While this is an area for future research, at the moment for the ease of analysis and modelling, other manuscript versions which are available on the CELT website have not been included. Thus, LL and its texts are the only ones under analysis in this paper.

\subsection{Dividing LL into texts}

There are several legitimate ways of viewing LL: as an indivisible complete work, or as the work of a group of scribes, or as a conglomeration of separate texts, or as the six-volume set as prepared by Best et al. (1954-1983). If LL is viewed in the first way, the analysis in this paper would not be possible as there would only be one text to analyse and the method proposed would not work. If LL is taken as the second, texts would need to be split by hand rather than by title. A slightly modified form of this analysis is attempted in the course of this chapter. If LL is viewed as the modern six-volume set, it would, much like the indivisible complete work, contain too few texts to analyse using the proposed method. Thus, for the purposes of this paper, LL will be viewed as the third type, a collection of 
separate texts collected into one whole work by a group of scribes. This policy accords well with Duncan's (2012: 28) argument on the composition of LL:

To regard Lebor na Nuchongbála as a single manuscript does not allow for its complexity either physically, palaeographically, or textually, and gives the impression that it was written at the same time and place in a straight run.

The CELT XML edition is composed of TEI XML files which correspond to each published volume of Best et al. (1954-1983). Within these files each text is divided by a <div1 $>$ XML tag. Each of these were extracted by use of two XSLT documents in succession using the SAXON XSLT engine. From there, a further use of $\mathrm{XPath}$ is made to extract the textual information and place it in files given names based on the <div1 $>$ tags which eased further analysis. All computer code to accomplish this is available at https://github.com/cyocum/bol_project.

Not all texts as extracted by the method above were used in the subsequent analysis. The texts that were not included, are:

- Haec sunt nomina virorum componentium lapides

- Lebor Gabála Érenn

- Togáil Troí

- Prose Dindsienchas

- Metrical Dindsienchas

- All Genealogies

- All King Lists

As the reader will undoubtedly notice, most of the texts are king lists or other kinds of lists. These texts do not give enough of the kinds of information necessary to create a good representation of the texts that are of interest to this kind of analysis. In addition, as will be shown below, they may distort the outcome of this exercise. Moreover, Lebor Gabála has been excluded because it has a complex textual history of its own and may confuse the analysis (Scowcroft 1987: 81-89). The consequence of this policy is that texts which are identified by author within Lebor Gabála are not included. For instance, a text of Flann Mainistrech's poem Éstid a eolchu cen ón and Gilla Cóemáin's Góedel Glas ó tat Goídil and Tigernmas mac Follaig aird are not included in the analysis. As Peter Smith (2007: 27) states: "Both Góedel Glas ó tat Goídil and Tigernmas mac Follaig aird appear to have formed an intrinsic part of Lebor Gabála since their composition.” The inclusion of the texts with identified authors but considered within Lebor Gabála would distort the analysis as the texts would be mixed with whomever transmitted the LL recension of Lebor Gabála. Similarly, Togáil Troí was excluded due to its own complicated textual history as described in Mac Gearailt (2016). The exclusion of the Prose and Metrical Dindsienchas is because these texts are similar in structure to Lebor 
Gabála in that Prose and Metrical Dindsenchas contain component texts. Additionally, the prose and metrical versions also appear together in most versions of the text (Theuerkauf 2017: 49-50). Attempting to extract and examine these texts would overburden the methodology to the detriment of the illustrative purposes of this chapter. A coherent method of extracting these kinds of texts from their surrounding textual context both in a single manuscript and in many versions across manuscripts deserves a far more thorough examination than can be accomplished here. Having such a methodology would allow an unsupervised machine learning method to be applied while remaining faithful to their history and context. Additionally, there are three texts which were not included in the CELT XML of the Book of Leinster but were used in the analysis, namely: Táin Bó Culinge, Fingal Rónáin, and Esnada Tige Buchet. These were supplemented from additional CELT files.

\subsection{From texts to vectors}

There are two generally accepted forms of text tagging for anonymous author attribution (Juola 2008: 262-266). First is part-of-speech tagging (hereafter, POS). This form of analysis uses a set of tags which mark the text for parts of speech. Using a method called Maximum Entropy, other untagged texts of the same language can be POS tagged (Jaynes 1957a, 1957b). Middle Irish does not have a POS tagger at the moment. POS tagging without an automatic POS tagger is extremely time-consuming and would be impossible in this instance. Lash (2014a) has constructed a corpus of POS tagged texts in Old/Middle Irish, which could form the basis for a POS tagger in the future. Additionally, there is the new Corpus Palaehibernicum (CorPH) (see the introduction to this volume), which could also help in this regard. However, the accuracy of automatic POS tagging can cause errors in itself:

. . . especially for POS taggers, is the introduction of errors in the processing itself; a system that cannot distinguish between contraction apostrophes and closing single quotes or that can only tag with $95 \%$ accuracy will conflate entirely different syntactic constructs, muddying the inferential waters.

(Juola 2008: 265)

The second type is function word tagging. Famously, function word tagging was used in identifying the authorship of the Federalist Papers (Mosteller and Wallace 1963). The Federalist Paper were a set of anonymously written essays to promote the ratification of the Constitution of the United States of America. Function word tagging is less time-consuming and a proven way of identifying anonymous authorship and was therefore the chosen method for this exercise. 
Function words are words which have no lexical meaning in a sentence and serve only to structure the sentence grammatically. In English, this includes words like of, and, $a$, an, etc. In early Irish, this includes but is not limited to pronouns sí 'she', prepositional pronouns duit 'to you', conjunctions (7), and definite articles in, int 'the'. Difficulties arise when infixed pronouns are encountered in the various texts. Infixed pronouns were left out of this analysis on the grounds that it would be difficult, but not impossible, to add them cleanly while not disturbing the creation of the document vector, more on which below.

In LL, there are 1,125 different categories of function words. The number of categories is large because there is no normalisation done during the counting of the words. This means variant spellings and initial mutations of words are left unnormalised. Thus n-uile 'all' is counted separately from plain uile 'all'. The consequences of this choice will be explored later as it has bearing upon the mathematics involved. Of the 189,472 words, as mentioned above, there are a total of 56,513 function words which means that there are an average of 344.59 function words per text. As there are so many function words, to list them here would be impractical so the total raw frequency can be found online. ${ }^{1}$

Once the tagging is finished, the $t f^{*} i d f$, which stands for term frequency times inverse document frequency, is calculated as shown below. Term frequency in the formula $t f^{\star} i d f$ means that the frequency of function words in a document is a major factor in determining the author of the document, which according to Zhong and Ghosh (2005) gives the best results for this kind of analysis.

Let $D$ be the set of all documents under consideration and $N$ be the number of documents in the set. For LL, $N=164$. The normalised frequency $t f(t, d)$ of a term $t$ in a document $d$ is computed thus:

$$
t f(t, d)=\frac{f(t, d)}{\max \{f(w, d): w \in d\}}
$$

In other words, the term frequency of a term in a document is the number of times that term appears in that document, denoted $f(t, d)$, divided by the maximum raw frequency of any term in that document, denoted $\max \{f(w, d): w \in d\}$. This includes non-functional terms (in other words, terms that have semantic meaning: nouns, verbs, etc.).

The inverse document frequency, idf, is then computed thus:

$$
\operatorname{idf}(t, D)=\log \left(\frac{N}{|\{d \in D: t \in d\}|+1}\right)
$$

1 https://github.com/cyocum/bol_project/blob/master/raw_frequency.txt 
In other words, the logarithm of the number of documents in the corpus divided by the number of documents where the term $t$ appears. It is common to adjust for the fact that term $t$ may not appear and thus one is added to it, which avoids divide by zero situations.

Finally, the $t f^{\star} i d f$ is calculated thus:

$$
t f i d f(t, d, D)=t f(t, d) \times i d f(t, D)
$$

This is calculated for each possible function word in a text. The $t f^{\star} i d f$ is welldefined for all words in the corpus but only function words are of interest here. Not all function words occur in all texts; if a term $t$ does not occur in a document $d$, then $t f(t, d)$ is 0 and hence $t f i d f(t, d, D)$ is also 0 .

We pick an ordering, which, while random, must be fixed as discussed below, $t_{0}, t_{1}, \ldots, t_{n}$ of function words, and an ordering $d_{0}, \ldots, d_{N-1}$ of documents, and for each document $d_{j}$ we form a document vector:

$$
\left(w_{1, j}, w_{2, j}, \ldots, w_{k, j}\right)
$$

where $w_{i, j}=t f i d f\left(t_{i}, d_{j}, D\right)$. The document vector is a list of the $t f^{\star} i d f$ values as defined above.

The fixed ordering of words allows comparisons across documents. For instance, if 7 (ocus 'and') is first in the list, then the $t f^{\star} i d f$ for 7 would be the first component of any document vector. Putting this all together, LL gives rise to a list of vectors (or a list of lists) of $t f^{\star} i d f$ values for each document. A list of vectors is called a matrix. It is an interesting feature of the LL that this matrix is sparse, as many of the entries in the vectors are 0.

\subsection{From matrix to clusters: $k$-medoids}

Once the matrix of the $t f^{\star} i d f$ of each function word which appears in a particular text has been calculated, the entirety of LL is ready for the next stage in its transformation. There are many different means of taking the digitised corpus and determining the possible clusters. The most common of these and the one that will be used here is called $k$-medoids, which was first introduced in Kaufman and Rousseeuw (1987) (see also MacQueen 1967). Additionally, while there are numerous statistical packages available to complete the last leg of the journey from text to mathematical object, the technical computing programming language Julia was chosen to compute and graph the final results (Bezanson et al. 2012).

The $k$-medoids algorithm uses a distance metric to partition the matrix (Park and Jun 2009). In this case, the cosine distance is used (see Tan, Steinbach, and 
Kumar 2005: 500 and Singhal 2001). The optimal partition is then found and all texts are placed in the optimal clusters based on their cosine distance from each other and the possible number of clusters. In other words, texts are placed together in one cluster when the algorithm determines that their vectors are close to each other. The output of the algorithm is called a clustering solution. The clustering solution must then be interpreted, which means that the results may demonstrate author attribution, genre, or scribal activity (Stamatatos 2009: 23). All these possibilities will be explored below.

One drawback of the $k$-medoids algorithm is that it does not estimate the number of clusters and thus, the number of clusters must be supplied. There is research into estimating the number of clusters; however, the research has not yet reached a point at which researchers are comfortable with the accuracy of the results (Maitra and Ramler 2010: 380; see also Solka 2008: 103).

What this means in practice is that the scholarship on early Irish literature drawn upon above plays a role in considering accuracy of the results. Results which approximate what other scholars have determined using traditional methods are taken as being more credible than those which do not. However, this does not mean that a slavish attitude toward either the computational results or the previous scholarship should be taken. If the results do not reflect what is expected, this could mean that continuing investigations are warranted to determine the exact reason for the differences and what these mean for the LL text clustering question.

\subsection{Normalisation and Principle Component Analysis}

Consider the matrix of LL: the frequency of each function word is often 0 and the number of possible function words is 1,125. In this context, each function word represents a dimension along which the vector resides. In other words, the vector space within which LL sits has 1,125 dimensions. When the $k$-medoids algorithm is applied to such a space, the number of dimensions contributes to the difficulty of finding optimal clusters.

This argues for the use of orthographic normalisation to reduce the number of potential function words and hence dimensions with the intention of reducing the size of the space and obtaining more optimal clusters. However, normalisation is not a simple operation in the context of early Irish orthography. First removing initial mutations would reduce the number of dimensions but not by much. After this was done, a more difficult task would present itself: which one of the different orthographic variations would be appropriate? In addition, if one from a particular linguistic period was chosen, would this force other texts 
which may have been written earlier or later to act like the normalised version? For the purposes of this study, this is a problem that is bearable. The complications of normalisation are high and deserve their own discussion, which is outside the scope of the current examination.

In any case, a far more sophisticated and illuminating method than normalisation is known as Principal Component Analysis (Abdi and Williams 2010) which attempts to capture as much of the variance as possible in as few dimensions as possible. Additionally, Principal Component Analysis allows visualisation of $k$-medoids.

As one can see from the graph below (Figure 1), a majority of texts in LL fall in a fairly small range. This means that the variation between the texts is fairly small or the texts in LL were either picked carefully to be very similar or they were edited in the process of copying to be more similar to each other. The farthest outliers in Figure 1 are: on the x-axis, Dindgnai Temrach and, on the y-axis, Cóica epscop dodeochatar dochum Moedoc Ferna do Bretnaib Cille Muine and Drochcomaithech robai i n-ocus dosom. The Principal Component Analysis ultimately shows that the texts have fairly low variance, which means that the use of function words tends to be uniform across the texts included in the analysis. One interpretation of this result is that the scribes could have chosen texts which used function words in a regular fashion. Another, more likely interpretation, and commonly understood by modern scholarship, is that the scribes were involved in not only copying texts but also changing those texts and by those changes, used function words in a consistent fashion.

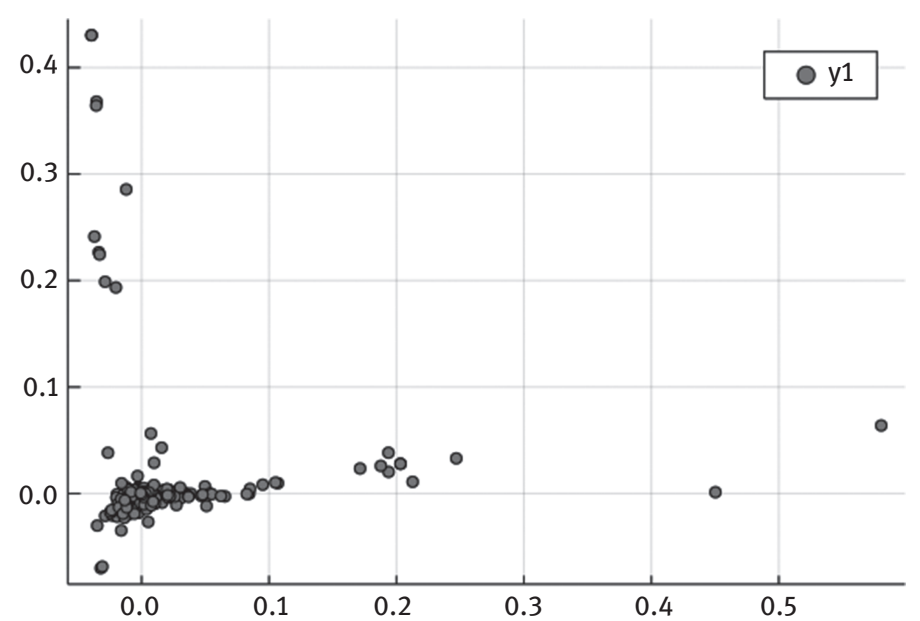

Figure 1: Principle Component Analysis. 


\section{Analysis}

As shown above in the discussion of Principal Component Analysis, the variation between the texts is constrained. Without more texts and texts which contain more variation in the use of function words, this makes any clustering solution rather weak. However, pressing on with the final calculations will demonstrate how to interpret and analyse the results of machine learning techniques on early Irish material. Therefore, three differing classes of further analysis will be presented. The first uses known authors as the basis upon which to understand the clustering solutions provided. The second will investigate the scribal hands as the main basis to understand the clusters provided. The third will use genre identification as the main method to understand the clustering solution provided by the $k$-medoids algorithm.

\subsection{Authors}

Once all the calculations from above are complete, the texts are ready for the final step. In this section, two k-medoid analyses will be presented. As stated above, estimating the number of clusters is still an area of active research. Thus, attempting to estimate the number of clusters is a subjective process. A method is to use a set of texts which have a known author, then attempt to fit that set to the output of $k$-medoids. For illustrating the analytic techniques involved in unsupervised machine learning analysis, two known authors who may assist in evaluating the accuracy of any particular cluster solution are used: Flann Mainistrech and Gilla Cóemáin (Smith 2007), who both wrote historical poems which are included in LL and are fairly well known. There are other known authors in LL. For instance, Fothad na Canone, Ailill Ólomm, and Flan Fína but they will not be included in the analysis to keep the points being illustrated here clear. For instance, In the case of Flann Mainistrech, poems attributed to him in LL are listed below as presented by Pődör (1999):

- Éstid a eolchu cen ón [Listen, scholars, without flaw]; as stated above in 2.1, this is not included.

- Ríg Temra dia tesbann tnú [The kings of Tara, without envy]

- In éol dib in senchus sen [Do you know the old tradition ... ? ?]

- Mide maigen Chlainne Cuinn [Mide, homestead of the descendants of Conn] (Smith 2001: 108-144)

- Cia triallaid nech aisnis [Whoever attempts to tell the story] (Gwynn 1991 [1903-1935], 4: 100-107) 
- Cind cethri $n$-dini iar Frigrind [At the end of four generations after Frigriu] (MacNeil 1913: 48-54)

- Ascnam ní seól sadail [Let us proceed - it is no easy undertaking] (MacNeill 1913: 48-58)

- Aní do ronsat do chalma [What Eogan's race have done of valiant deeds] (MacNeill 1913: 59-70)

- An gluind, a n-echta [Their deeds, their death-dealings] (MacNeill 1913: 70-82)

- Mugain ingen Chonchraid chain [Mugain, daughter of righteous Concrad]

- Sil Aeda Slaine na sleg [The race of Aed Sláne of the spears] (MacNeill 1913: 92-99)

While not included in Pődör's list, the following is also added:

- Rig Themra toebaige iar tain [The kings of many sided Tara, after that]

- A Gillu gairm n ilgrada [O lads of the names of great rank]

The list of poems ascribed to Gilla Cóemáin are listed below (Smith 2007: 25-7):

- Hériu ard inish na rríg [Lofty Ireland, island of the kings] (Smith 2007: 104-169)

- At-tá sund forba fessa [Herein is the apex of knowledge] (Smith 2007: 170-187)

- Annálad anall uile [All the annal-writing heretofore] (Smith 2007: 188-211)

With the above in mind, it is time to consider the $k$ in $k$-medoids. The variable $k$ represents the number of clusters to which a solution is found by the algorithm. ${ }^{2}$ The clustering solution places all texts in LL into the number of clusters as signified by $k$. A cluster could mean an author so that $k$ could equal the number of authors of LL. The possibility that clusters do not represent authors is explored below. As previously mentioned, there is no reliable way yet to estimate the number of clusters in a clustering solution. This leaves $k$ as arbitrary, although not wholly so. In particular, the method chosen for this chapter is that $k$ is adjusted iteratively until the texts begin to coalesce into clusters which look like the above list of texts. This began to happen when $k \rightarrow 15$. Using a technique called a Silhouette, which is described below in section 3.3, the choice is further refined until it was decided to use $k=27$, which gave the best clustering solution and thus 27 authors of LL. ${ }^{3}$ As

2 The full clustering solutions in CSV format for each value of $k$ used in this paper are available at: https://github.com/cyocum/bol_project/tree/master/clustering_solutions.

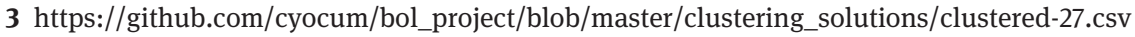


mentioned above previously, known authors can constrain $k$ to a number in which their texts begin to cluster together. As explained above, to test this hypothesis, we use known authors with known lists of texts in LL. First we will examine Flann Mainistrech and where the texts which are attributed to him fall within this list.

Table 1 is subset of the clustering solution for all the texts of LL for which Flann Mainistrech is the attributed author. The Cluster ID is the number of the cluster which is assigned by the algorithm. All texts assigned the same Cluster ID are within the same cluster. As the reader will notice, not all of Flann's texts are clustered together and a few are spread out among different clusters. Moreover, one will also notice that all the poems in cluster 10 are of the same genre, in particular, they are all historical poems which have many personal names in them, which reduces the overall frequency of function words. The reason for this may be that the style and meter are tightly constrained and thus, the function word use is similar across all the poems. This might mean that there are fewer function words and that the same ones are used frequently. However, authorship may still be preserved. These results may just be a consequence of the choice of known authors, who are both noted for writing mostly historical poems. A fuller analysis of this phenomenon will be discussed below.

Table 1: Flann Mainistrech where $\mathrm{k}=27$.

\begin{tabular}{|c|c|c|c|c|}
\hline Cluster ID & Title & Volume & $\begin{array}{l}\text { Scribe } \\
\text { (Schlüter) }\end{array}$ & $\begin{array}{l}\text { Scribe } \\
\text { (Duncan) }\end{array}$ \\
\hline None & Éstid a eolchu cen ón & 1 & None & None \\
\hline 10 & Ríg Temra dia tesbann tnú & 3 & U & $u$ \\
\hline 10 & Mide magen clainne Cuind & 4 & U & $U$ \\
\hline 10 & Cind cethri ndini iar Frigrind & 4 & U & $\mathrm{U}$ \\
\hline 10 & Síl Aeda Sláne na sleg & 4 & U & $u$ \\
\hline 10 & $\begin{array}{l}\text { Aní doronsat do chalmu clanna } \\
\text { Eogain }\end{array}$ & 4 & U & $U$ \\
\hline 10 & Ascnam ni seol sadal & & $\mathrm{U}$ & $U$ \\
\hline 3 & $\begin{array}{l}\text { Angluind a n-echta a n-orgni batar } \\
\text { infhir }\end{array}$ & 4 & $\mathrm{U}$ & $U$ \\
\hline 3 & Inn eól dúib in senchas sen & 3 & $\mathrm{U}$ & $\mathrm{U}$ \\
\hline 6 & Mugain ingen Chonchraid chain & 3 & U & $U$ \\
\hline 6 & A Gillu gairm n ilgrada & 1 & $\mathrm{~T}$ & $\mathrm{~T} 2$ \\
\hline
\end{tabular}


Moving to Gilla Cóemáin, the situation is even more pronounced:

Table 2: Gilla Cóemáin where k = 27.

\begin{tabular}{llrll}
\hline Cluster ID & Title & Volume & Scribe (Schlüter) & Scribe (Duncan) \\
\hline 10 & Hériu ard inis na rríg & 3 & $\mathrm{~A}$ & $\mathrm{~A}$ \\
\hline 11 & Attá sund forba fessa & 3 & $\mathrm{U}$ & $\mathrm{U}$ \\
\hline 17 & Annalad anall uile & 3 & $\mathrm{U}$ & $\mathrm{U}$ \\
\hline
\end{tabular}

None of Gilla Cóemáin's historical works falls into the same clusters. This surprising result shows that our assumptions regarding ascription of the texts to Gilla Cóemáin may be incorrect in this instance. On the one hand, that Hériu ard inis na rríg clustered with historical texts by Flann Mainistrech does in cluster 10 may mean that there is enough information to cluster it with other historical poems. On the other hand, that Analad anall uile clusters with other historical poems in cluster 17 marginally supports an argument that the cluster algorithm is identifying genre rather than authorship. As for Attá sund forba fessa in cluster 11, this poem is in the same cluster as another didactic poem, Sluindfet duib dagaisti in dana (Thurneysen 1912: 73-77) and a poem about a quarrel between an old woman and a retainer of the king of Leinster, A bairgen ataí i ngábud (Ua Nualláin 1904). However, this does not negate the interpretation of clustering solutions as authorship. Ultimately, it means that Gilla Cóemáin may not have written these texts and these texts are being placed with their anonymous authors who may have also written historical poems. In addition, the limitations of the present methodology may be interfering with the placements of the texts.

\section{$3.2 k=20$}

The only change between this clustering solution and the previous one is that $k$ was set to 20 rather than $27 .{ }^{4}$ All other parameters were kept the same for the sake of consistency and comparison. As would be expected, the change in the clustering solution is small. Most texts stay in the same clusters even if the cluster numbers have shifted. However, some texts like Cia triallaid nech aisnis, which was in the same cluster as those identified with Flann Mainistrech in the case of $k=27$

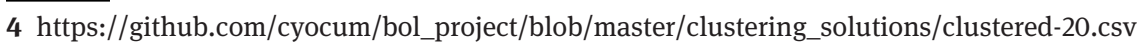


where $\mathrm{k}=20$ (see Table 3 below), have moved. This means that the text was probably near the boundary between two clusters, and thus two authors, and was assigned to the correct author by $k$-medoids but when the number of clusters changed, the text was assigned to a new cluster based on the new boundaries calculated. This situation is why a quality check as described below using Silhouettes and previous scholarship on early Irish literature are consulted to detect these situations and determine the best clustering solution.

Table 3: Flann Mainistrech where $\mathrm{k}=20$.

\begin{tabular}{llrll}
\hline Cluster ID & Title & Volume & Scribe (Schlüter) & Scribe (Duncan) \\
\hline None & Éstid a eolchu cen ón & 1 & None & None \\
\hline 2 & $\begin{array}{l}\text { Aní doronsat do chalmu } \\
\text { clanna Eogain }\end{array}$ & 4 & $\mathrm{U}$ & $\mathrm{U}$ \\
\hline 9 & $\begin{array}{l}\text { Mugain ingen Chonchraid } \\
\text { Chain }\end{array}$ & 3 & $\mathrm{U}$ & $\mathrm{U}$ \\
\hline 11 & Cia triallaid nech aisnis & 4 & $\mathrm{U}$ & $\mathrm{U}$ \\
\hline 14 & A Gillu gairm n ilgrada & 1 & $\mathrm{~T}$ & $\mathrm{~T} 2$ \\
\hline 19 & Mide magen clainne Cuind & 4 & $\mathrm{U}$ & $\mathrm{U}$ \\
\hline 19 & Cind cethri ndíni iar Frigrind & 4 & $\mathrm{U}$ & $\mathrm{U}$ \\
\hline 19 & Síl Aeda Sláne na sleg & 4 & $\mathrm{U}$ & $\mathrm{U}$ \\
\hline 19 & Ascnam ní seól sadail & 4 & $\mathrm{U}$ & $\mathrm{U}$ \\
\hline 19 & $\begin{array}{l}\text { Angluind a n-echta a n-orgni } \\
\text { batar infhir }\end{array}$ & 4 & $\mathrm{U}$ & $\mathrm{U}$ \\
\hline 19 & Inn eól dúib in senchas sen & 3 & $\mathrm{U}$ & $\mathrm{U}$ \\
\hline 19 & Ríg Themra dia tesband tnú & 3 & $\mathrm{U}$ & $\mathrm{U}$ \\
\hline 19 & Rig Themra toebaige iar tain & 3 & $\mathrm{U}$ & \\
\hline
\end{tabular}

For Gilla Cóemáin, the clustering solution where $\mathrm{k}=20$ (see Table 4 below) is much the same. There is no overlap between his known historical poems and the cluster solution.

While the focus has been on Flann Mainistrech and Gilla Cóemáin, there are other indications that the clustering solution is registering authorship rather than style. If the analysis is done with $k=5$, one will notice that Fothad na Canone, Ailill Ólomm, and Flan Fína's texts will cluster together. Thus, it 
Table 4: Gilla Cóemáin where k = 20.

\begin{tabular}{llrll}
\hline Cluster ID & Title & Volume & Scribe (Schlüter) & Scribe (Duncan) \\
\hline 4 & Annalad anall uile & 3 & $\mathrm{U}$ & $\mathrm{U}$ \\
\hline 15 & Attá sund forba fessa & 3 & $\mathrm{U}$ & $\mathrm{U}$ \\
\hline 19 & Hériu ard inis na rríg & 3 & $\mathrm{~A}$ & $\mathrm{~A}$ \\
\hline
\end{tabular}

seems given the amount of clustering in both Flann and other cases that this method gives clues as to the underlying authorship of various texts in LL.

\subsection{Silhouettes}

While the above may, at first glance, look like an open and shut case for the case in which the clustering and the scholarship coincide, there is more to the story than Flann and Gilla. Silhouettes are used to validate and interpret clustering solutions (Rousseeuw 1987). Silhouettes are a measure of how well each text resides in its cluster and thus the quality of the clustering solution.

The Silhouette histogram (Figures 2 and 3) is a graph which has an $\mathrm{x}$-axis that is bounded between -1.0 and 1.0. The closer to 1.0 a text falls, the further away it is from its cluster. The closer to 0 a text falls, the closer the text is on the boundary between clusters. The closer to -1 a text falls, the closer the text is to the wrong cluster. The y-axis counts how many texts have the same value on the $\mathrm{x}$-axis. Ideally, there should be more bars on the positive side of 0.0 on the $\mathrm{x}$ axis, meaning the text is in the correct cluster, for a good clustering solution.

As one can see in both the case where $k=20$ (Figure 2) and where $k=27$ (Figure 3), a large number of texts fall on the border between two clusters, around zero on the $\mathrm{x}$-axis on the graph. This means that they fall on the edges of clusters and many others fall in the negative area on the x-axis. In turn, this means that they are probably in the wrong cluster. This is true for most clustering solutions used in the analysis. Increasing the number of clusters (the size of $k$ ) should provide a solution for this but, as stated above, texts which are known to be composed by different authors start to be placed into the same clusters so given: the constraints of known authorship, the use of function words rather than POS tagging, since $k=27$ has numerically more texts on the positive side of 0.0 on the $\mathrm{x}$-axis than $k=20, k=27$ is the best clustering solution presently available. In fact, none of the clustering solutions are entirely satisfactory. Once an accurate POS tagger for Old and Middle Irish is created, the results from applying 
$k$-medoids on the vectors created from the POS tagger can then be investigated and checked against the current analysis to see how well this method worked and how well, overall, these statistical methods can work with material like the Old and Middle Irish corpus.

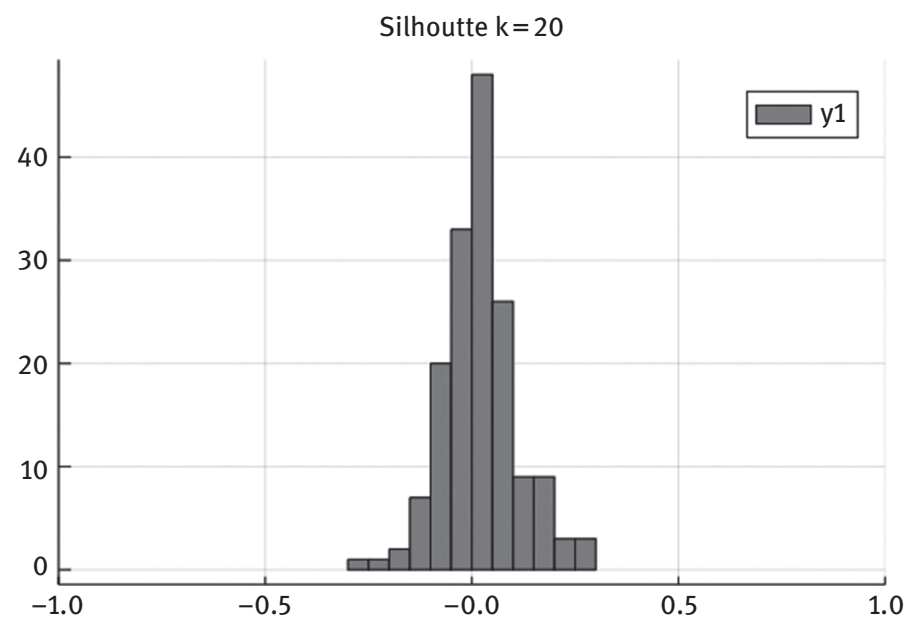

Figure 2: Silhouette where $\mathrm{k}=20$.

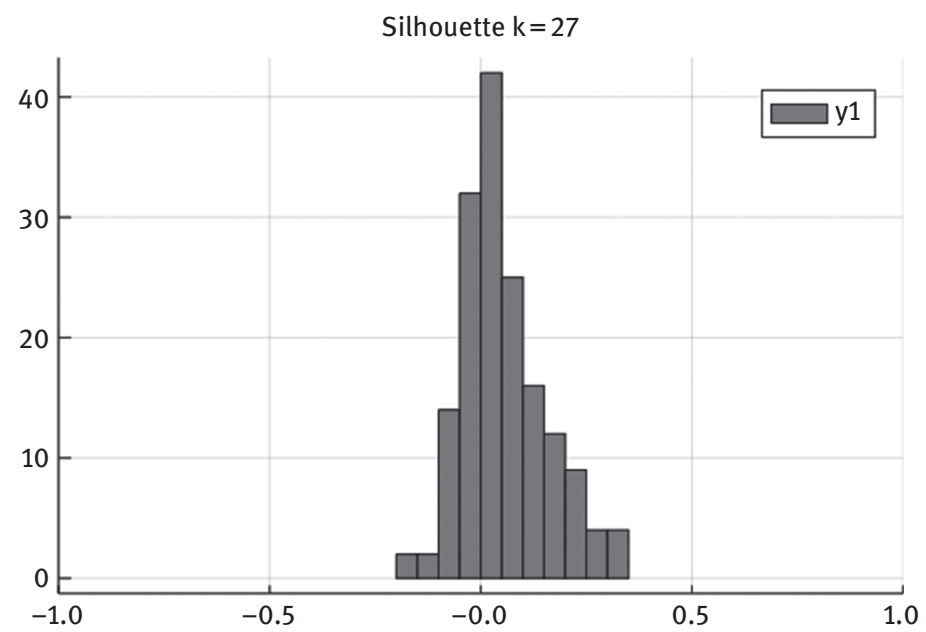

Figure 3: Silhouette where $\mathrm{k}=27$. 


\subsection{Scribes}

As is well-known, scribes in medieval Ireland were not above making changes to their source material. This included updating the language in various ways: modernising the spelling, moving sentences, and, most importantly for this analysis, changing function words in various texts (Boyle and Hayden 2014: xxxvii-xlvi). Thus, while an argument can be made that $k$-medoids analysis can identify authors, there is an equally strong chance that the texts cluster because of this kind of scribal "editorial" activity regardless of the ascribed authorship.

Elizabeth Duncan has identified and catalogued the various folios to the nine scribes of LL (Duncan 2012). She does not, however, give a table of folios to texts. Duncan's tables can be supplemented by the appendix supplied by Schlüter (2010: 226-243), which does give the scribal hand to text. Correlating the two tables gives a good indication of what each scribe wrote. In the case of overlapping scribal activity, the text is awarded to the scribe who contributed the most number of folios to a particular text. This is, of course, arbitrary and open to criticism but it suits the purposes of this analysis.

Using $k$-medoids analysis on the scribes of LL is much simpler than attempting the analysis for authors because much more is known about the hands involved in the manuscript and the fact that scribes sometimes claim, by, for instance adding a note above the beginning of a text, that a text was written by an incorrect author is not as much of a problem. The physical activity of the scribes means that there is less uncertainty surrounding which scribe wrote what section of text than attempting a more speculative analysis of authorship.

The results for the clustering solution where $k=9$ (see Appendix) show that the scribes' works admix freely and do not necessary cluster together as one would expect if scribes were strongly represented in the texts. This indicates that the scribes were not strongly influencing the texts themselves.

\section{Genre}

Defining different genres in early Irish literature is a problem which has exercised both the early Irish themselves and modern scholars. The problem is one of principles of categorisation. While modern scholars tend to organise the tales into a series of "cycles", the medieval Irish organised the tales by the main action of the story (for discussion on medieval Irish literary theory, see Coileáin 1974; Backhaus 1990; Poppe 1999, 2008; Stam 2010: 66-68). Mac Cana (1980: 41-73) compiled the canonical list of medieval Irish genres in The Learned Tales of 
Medieval Ireland from manuscript source, a summary of which is given below. There are twenty genres according to Mac Cana's list. In other words, does $k=20$ cause the texts to fall into the same order of genres as proposed by Mac Cana (1980: 73-81)? If this is the case, then $k$-medoids could be clustering by genre as defined in the tale lists rather than by author (Juola and Baayen 2005).

- Aided 'death-tale, violent death'

- Aithed 'elopement'

- Baile/buile 'vision, frenzy'

- Cath 'battle'

- Compert 'conception, begetting, procreation'

- Echtra(e) 'expedition, journey (to the otherworld), adventure'

- Fess/feis 'feast'

- Fis 'vision'

- Forfess/forbais 'beleaguering, seige, night-watch'

- Im(m)ram 'sea-voyage'

- Orcrain/orcun 'murdering, ravaging'

- Serc 'love'

- Slúagad/slógad 'a hosting, a military expedition'

- Táin 'driving off, cattle raid'

- Tochmarc 'wooing, courting'

- Togail 'attack, destruction; attacking destroying'

- Tomaidm 'bursting forth of lake or river'

- Úath 'terror, horror' (although it seems to be a late genre) (Mac Cana 1980: 81)

A simple example will suffice for an answer. In the clustering solution for $k=20,{ }^{5}$ four Aided tales (Aided Cheltchair meic Uthechair, Aided Cuanach meic Ailchini, Aided Derb Forgaill, Aided Meidbe) appear in cluster 11; however, this is misleading as the cluster is the largest with forty entries, which will not be shown here as it would be impractical (see rather the data referenced in footnote 5), and contains many other kinds of tales which are obviously not related. Two other Aided texts appear in cluster 2 but cluster 2 contains twenty-two other texts. While this is one example genre, it holds true for the other tale types. Especially since some of them cluster together with each other rather than in their own clusters. For instance, cluster 11 contains two táin texts (Táin Bó Flidais and Táin Bó Fraích) and two cath texts (Cath Carn Chonaill and Cath Maige Mucrima), which are among many texts that are decidedly not aided texts. This argues strongly against the clustering solution reflecting the early Irish tale lists.

5 See https://github.com/cyocum/bol_project/blob/master/clustering_solutions/clustered-20.csv 


\section{Conclusion}

The fundamental question asked at the beginning of this chapter was: how can unsupervised machine learning and statistical techniques be used in assessing authorship attribution in early Irish texts? An attempt was made to answer this question from a machine learning perspective using $t f^{\star} i d f$ and spherical $k$-medoids analysis to create a methodology from which a clustering solution was created using the Julia programming language. This methodology was then applied to LL with a number of texts removed for various reasons. Then a number of ways of understanding the clustering solutions was attempted: author, genre, and scribe. For authorship, the attributed texts in LL for Flann Mainistrech and Gilla Cóemáin were used to understand the clustering solutions $k=20$ and $k=27$. In this particular case, it seems that, while Flann Mainistrech's texts tend to cluster together, Gilla Cóemáin's do not, which would suggest that the texts ascribed to Gilla Cóemáin could possibly not been written by him but were written by others then subsequently ascribed to him. From the foregoing analysis, it would seem that there are 27 authors in LL. These clustering solutions were quality-assessed using Silhouettes, which showed some difficulties with the clustering solution. Two further clustering solutions were created: one that attempted to match known early Irish genres to clustered texts, and one that attempted to match clusters of texts to known scribal hands. In both cases, no correlation was found. This result suggests that scribal hands and genre are not useful when attempting to attribute authorship and should be avoided.

As identified in this paper, the methodology is strict; however, there is ample room for further improvement and research. For instance, the use of POS tagging rather than function words and the reduction of the dimensionality of the resulting matrix by using orthographic or other normalisation techniques should be investigated. This research may increase the accuracy and quality of the clustering solutions as identified using Silhouettes and bring more scholarly interest to this style of analysis. The method is not necessary conclusive, but rather suggestive and can help guide future research into the issue. In a broader sense, once the methodological difficulties are overcome, this methodology is possibly applicable to all of early Irish literature for which we have electronic versions.

Additionally, there is also room for more texts. For instance, Lebor Gabála was left out because of its complex textual and scholarly history. Moreover, the way in which the texts were separated in the electronic versions caused some known texts to be excluded. These exclusions directly influence the accuracy and reliability of the clustering solution. Further research into creating methods for extracting these texts in a coherent way, given that they are intimately 
bound into the textual history of their enclosing text, and presenting them for analysis is also necessary.

Using unsupervised machine learning techniques and methods as presented here to answer questions of authorship in early Irish opens up new avenues of research and discovery, not just for LL, but for the whole of early Irish literature.

\section{Appendix}

The clustering solution where $\mathrm{k}=9$ is presented below in Table 5 .

Table 5: $\mathrm{k}=9$.

\begin{tabular}{|c|c|c|c|c|}
\hline $\begin{array}{l}\text { Cluster } \\
\text { ID }\end{array}$ & Title & Volume & $\begin{array}{l}\text { Scribe } \\
\text { (Schlüter) }\end{array}$ & $\begin{array}{l}\text { Scribe } \\
\text { (Duncan) }\end{array}$ \\
\hline 1 & A Gillu gairm n ilgrada & 1 & $\mathrm{~T}$ & T1 \\
\hline 1 & Cinti crábuid gnathaigthe scoile Sinchil & 6 & A & $A$ \\
\hline 1 & $\begin{array}{l}\text { Cormac mac Culennain larfaiged nech acaib } \\
\text { dam }\end{array}$ & 1 & $\mathrm{~T}$ & $\mathrm{~T} 1$ \\
\hline 1 & $\begin{array}{l}\text { Diarmait mac Cerbaill mairg thocheas rí clerchib } \\
\text { ceil }\end{array}$ & 3 & U & $\mathrm{U}$ \\
\hline 1 & Dublitir hua Uathgaile rédig dam a Dé do nim & 3 & U & $\mathrm{U}$ \\
\hline 1 & Dubthach hua Lugair Andsu immarbáig ri Lagnib & 1 & A & A \\
\hline 1 & $\begin{array}{l}\text { Dubthach hua Lugair Crimthan clothrí cóicid } \\
\text { Hérend }\end{array}$ & 1 & A & A \\
\hline 1 & Feidlimid athair Echach & 1 & $A(?)$ & A \\
\hline 1 & Fland Fina in rigan ecanaid óg fíal & 3 & U & $A+U$ \\
\hline 1 & Fland Fina Ro ddet a hInis find Fáil & 1 & A & A \\
\hline 1 & Fland Mugain ingen Chonchraid chain & 3 & $\mathrm{U}$ & $\mathrm{U}$ \\
\hline 1 & Fothad na Canone Cert cech ríg co rréil & 3 & $\mathrm{U}$ & $\mathrm{U}$ \\
\hline 1 & Fothad na Canone Eclais Dé bí & 3 & $U$ & $U$ \\
\hline 1 & Gilla Cóemáin Annalad anall uile & 3 & $\mathrm{U}$ & $\mathrm{U}$ \\
\hline 1 & Gilla Mo Dutu Ádam óenathair na ndórene & 3 & $\mathrm{U}$ & $\mathrm{U}$ \\
\hline
\end{tabular}


Table 5 (continued)

\begin{tabular}{|c|c|c|c|c|}
\hline $\begin{array}{l}\text { Cluster } \\
\text { ID }\end{array}$ & Title & Volume & $\begin{array}{l}\text { Scribe } \\
\text { (Schlüter) }\end{array}$ & $\begin{array}{l}\text { Scribe } \\
\text { (Duncan) }\end{array}$ \\
\hline 1 & $\begin{array}{l}\text { Gilla in Chomded úa Cormaic a ríg ríchid reidig } \\
\text { dam }\end{array}$ & 3 & $\mathrm{U}$ & U \\
\hline 1 & $\begin{array}{l}\text { Gilla na Naem Hua Duind Cuiced Lagen na lecht } \\
\text { ríg }\end{array}$ & 1 & A & A \\
\hline 1 & $\begin{array}{l}\text { Mac Cosse of Ros Ailither Rofessa i curp domuin } \\
\text { dúir }\end{array}$ & 3 & $\mathrm{U}$ & $\mathrm{U}$ \\
\hline 1 & Teist Chathail meic Finguine & 3 & $U$ & $\mathrm{U}$ \\
\hline 1 & Trí Fothaid Elgga cen chron & 3 & $\mathrm{U}$ & $\mathrm{U}$ \\
\hline 2 & Angluind a n-echta a n-orgni batar infhir & 4 & $\mathrm{U}$ & $\mathrm{U}$ \\
\hline 2 & Ascnam ni seol sadal & 4 & $\mathrm{U}$ & $\mathrm{U}$ \\
\hline 2 & Brislech Mór Maige Muirthemni & 2 & $\mathrm{U}$ & $\mathrm{U}$ \\
\hline 2 & Cind cethri ndini iar Frigrind & 4 & $\mathrm{U}$ & $\mathrm{U}$ \\
\hline 2 & Cináed húa Artacáin Fíanna Bátar i nEmain & 1 & A & A \\
\hline 2 & Echta Lagen for Leth Cuind & 1 & A & A \\
\hline 2 & Fland Mainistrech Ríg Themra dia tesband tnú & 3 & $\mathrm{U}$ & $\mathrm{U}$ \\
\hline 2 & Fland Manistrech Inn eól dúib in senchas sen & 3 & $\mathrm{U}$ & $\mathrm{U}$ \\
\hline 2 & Gilla Cóemáin Hériu ard inis na rríg & 3 & A & A \\
\hline 2 & Guidim Comdid cumachtach & 1 & A & A \\
\hline 2 & Inis Dornglais ro gab Crimthann & 4 & A & A \\
\hline 2 & Mael Muru Othna Can a mbunadas na nGaedel & 3 & $\mathrm{U}$ & $\mathrm{U}$ \\
\hline 2 & Marb Cairpre Músc co n-áne & 1 & $\mathrm{~T}$ & $\mathrm{~T} 2$ \\
\hline 2 & Mide magen clainne Cuind & 4 & $\mathrm{U}$ & U \\
\hline 2 & Mugdorn ingen Moga Duib Conan gilla Find & 4 & A & A \\
\hline 2 & Ossin Ogum i llia lia úas lecht & 3 & $\mathrm{U}$ & $\mathrm{U}$ \\
\hline 2 & Síl Aeda Sláne na sleg & 4 & $\mathrm{U}$ & $U$ \\
\hline 2 & Turim Tigi Temrach & 1 & $\mathrm{~T}$ & $\mathrm{~T} 2$ \\
\hline 3 & A Maccáin ná cí & 3 & $U$ & $\mathrm{U}$ \\
\hline
\end{tabular}


Table 5 (continued)

\begin{tabular}{|c|c|c|c|c|}
\hline $\begin{array}{l}\text { Cluster } \\
\text { ID }\end{array}$ & Title & Volume & $\begin{array}{l}\text { Scribe } \\
\text { (Schlüter) }\end{array}$ & $\begin{array}{l}\text { Scribe } \\
\text { (Duncan) }\end{array}$ \\
\hline 3 & Ailill Ólomm beir mo scíath fri úath & 3 & $\mathrm{U}$ & $\mathrm{U}$ \\
\hline 3 & Aní doronsat do chalmu clanna Eogain & 4 & $\mathrm{U}$ & $\mathrm{U}$ \\
\hline 3 & Cinaed úa hArtacain a cholch thall for elaid úair & 3 & $U$ & $\mathrm{U}$ \\
\hline 3 & Dallán mac Móre Cerball Currig cáemLife & 1 & A & A \\
\hline 3 & Dían airing & 1 & $\mathrm{~T}$ & $\mathrm{~T} 1$ \\
\hline 3 & $\begin{array}{l}\text { Orthanach húa Cáellama A Chóicid chóem } \\
\text { Chairpri chrúaid }\end{array}$ & 1 & A & A \\
\hline 4 & A ben bennacht fort na raid & 5 & $\mathrm{~F}$ & $\mathrm{~F}$ \\
\hline 4 & Aided Derb Forgaill & 2 & $U$ & $\mathrm{U}$ \\
\hline 4 & Aided Meidbe & 2 & $U$ & $\mathrm{U}$ \\
\hline 4 & Audacht Morainn & 5 & $\mathrm{~S}$ & S \\
\hline 4 & Clanna Ailella Uluim uill & 3 & $U$ & $\mathrm{U}$ \\
\hline 4 & Cathcharpat serda & 4 & A & A \\
\hline 4 & De Gabail intSida & 5 & $\mathrm{~F}$ & $\mathrm{~F}$ \\
\hline 4 & De dúlib feda na fored & 1 & $\mathrm{~T}$ & $\mathrm{~T} 1$ \\
\hline 4 & Dá brón flatha nime & 5 & $\mathrm{~F}$ & $\mathrm{~F}$ \\
\hline 4 & Días macclerech & 5 & $\mathrm{~F}$ & $\mathrm{~F}$ \\
\hline 4 & Echtra Laegaire meic Crimthainn & 5 & $\mathrm{~F}$ & $\mathrm{~F}$ \\
\hline 4 & Fechtas aile do MLing is Toídin & 5 & (F?) & $\mathrm{F}$ \\
\hline 4 & Mo Lling Luachra dalta do Maehóc Ferna & 5 & $(\mathrm{~F} ?)$ & $\mathrm{F}$ \\
\hline 4 & Mo Lling Rochúala la nech légas libru & 3 & $\mathrm{U}$ & $\mathrm{U}$ \\
\hline 4 & Nuallguba Emire & 2 & $U$ & $\mathrm{U}$ \\
\hline 4 & Senchán Torpéist Apair ri sil nEogain Móir & 3 & $U$ & $U$ \\
\hline 4 & Slan seiss a Brigit co mbuaid & 1 & A & A \\
\hline 4 & Túathal Techtmar ba rí Temrach & 1 & $A(?)$ & A \\
\hline 4 & Esnada Tige Buchet & 5 & $\mathrm{~F}$ & $\mathrm{~F}$ \\
\hline
\end{tabular}


Table 5 (continued)

\begin{tabular}{|c|c|c|c|c|}
\hline $\begin{array}{l}\text { Cluster } \\
\text { ID }\end{array}$ & Title & Volume & $\begin{array}{l}\text { Scribe } \\
\text { (Schlüter) }\end{array}$ & $\begin{array}{l}\text { Scribe } \\
\text { (Duncan) }\end{array}$ \\
\hline 5 & Cu Chulaind atbert. De aduentu Christi & 2 & $\mathrm{U}$ & $U$ \\
\hline 5 & Maiccni Echach ard a nigle & 3 & $\mathrm{U}$ & $\mathrm{U}$ \\
\hline 6 & A Chormaic coisc do maicni & 3 & $\mathrm{U}$ & $\mathrm{U}$ \\
\hline 6 & Audacht Moraind & 6 & A & A \\
\hline 6 & Augaine Már mac ríg Hérend & 1 & $A(?)$ & A \\
\hline 6 & Ciaran cecinit & 6 & A & A \\
\hline 6 & Dialogue between Brendan and Moínenn & 6 & A & A \\
\hline 6 & Fiacail Patric & 6 & A & A \\
\hline 6 & Fochond Loingse Fergusa meic Roig & 5 & $\mathrm{~F}$ & $\mathrm{~F}$ \\
\hline 6 & Macclerech do muntir Ferna móire & 5 & $(F ?)$ & $\mathrm{F}$ \\
\hline 6 & Messe bad rí réil & 3 & $\mathrm{U}$ & $\mathrm{U}$ \\
\hline 6 & Senbriathra Fithail & 6 & A & A \\
\hline 6 & Tecosca Cormaic & 6 & A & A \\
\hline 6 & Táin Bó Flidais & 5 & $\mathrm{~F}$ & $\mathrm{~F}$ \\
\hline 7 & Brandub mac Echach & 1 & A & A \\
\hline 7 & Cethri srotha déc éicsi & 1 & $\mathrm{~T}$ & $\mathrm{~T} 1$ \\
\hline 7 & $\begin{array}{l}\text { Fithal } 7 \text { Cormac Níba mé linfes do neoch dara } \\
\text { thráth }\end{array}$ & 3 & $\mathrm{U}$ & $\mathrm{U}$ \\
\hline 7 & $\begin{array}{l}\text { Orthanach húa Cáelláma Masu de chlaind } \\
\text { Echdach aird }\end{array}$ & 1 & A & T1 (over A) \\
\hline 7 & Secht mbémmend Brandub for Brega & 1 & A & A \\
\hline 8 & Birth of Brendan & 6 & A & A \\
\hline 8 & Broccán Craibdech Lecht Cormaic meic Culennáin & 1 & A & A \\
\hline 8 & Bórama & 5 & $\mathrm{~S}$ & $\mathrm{~S}$ \\
\hline 8 & $\begin{array}{l}\text { Cellach Húa Rúanada sluindfet dúib dagaisti in } \\
\text { dana }\end{array}$ & 1 & $\mathrm{~T}$ & $\mathrm{~T} 1$ \\
\hline
\end{tabular}


Table 5 (continued)

\begin{tabular}{|c|c|c|c|c|}
\hline $\begin{array}{l}\text { Cluster } \\
\text { ID }\end{array}$ & Title & Volume & $\begin{array}{l}\text { Scribe } \\
\text { (Schlüter) }\end{array}$ & $\begin{array}{l}\text { Scribe } \\
\text { (Duncan) }\end{array}$ \\
\hline 8 & Cethrur ar fichet nosfail & 6 & A & A \\
\hline 8 & Clanna Falge Ruis in ríg & 1 & A & A \\
\hline 8 & Colum Cille cecinit & 6 & A & A \\
\hline 8 & Connachta cid dia tá in t-ainm & 1 & $\mathrm{~T}$ & $\mathrm{~T} 1$ \\
\hline 8 & Cuan Hua Lothchain Temair breg bale na fian & 1 & A & A \\
\hline 8 & Epscop lbar & 6 & A & A \\
\hline 8 & Gilla Cóemáin attá sund forba fessa & 3 & $U$ & $\mathrm{U}$ \\
\hline 8 & Rig Themra toebaige iar tain & 3 & $\mathrm{U}$ & $\mathrm{U}$ \\
\hline 8 & Sarbili anim Mo Ninni & 6 & A & A \\
\hline 8 & Scrín Adomnáin & 6 & A & A \\
\hline 8 & Trea ropo maith in ben & 6 & A & A \\
\hline 8 & Táin Bó Cúalnge & 2 & $T(+F)$ & $\mathrm{T} 1+\mathrm{F}$ \\
\hline 8 & Étsecht Luin Garad & 6 & A & A \\
\hline 8 & Úar in lathe do Lum Luine & 3 & $U$ & $U$ \\
\hline 9 & A bairgen ataí i ngábud & 1 & A & A \\
\hline 9 & Aided Cheltchair meic Uthechair & 2 & $\mathrm{U}$ & $\mathrm{U}$ \\
\hline 9 & Aided Choncobuir & 2 & $U$ & $\mathrm{U}$ \\
\hline 9 & Aided Cuanach meic Ailchini & 5 & $F+A$ & $\mathrm{~F}$ \\
\hline 9 & $\begin{array}{l}\text { Aided Guill meic Carbada } 7 \text { Aided Gairb Glinne } \\
\text { Rigi }\end{array}$ & 2 & $U$ & $U$ \\
\hline 9 & Aigidecht Aithirne & 2 & $U$ & U \\
\hline 9 & Baí rí amra de Grécaib Salemón a ainm & 5 & $\mathrm{~F}$ & $\mathrm{~F}$ \\
\hline 9 & Beochobra Con Culaind isind ló fúair bás & 2 & $\mathrm{~F}$ & $\mathrm{U}$ \\
\hline 9 & $\begin{array}{l}\text { Buí siur Mo Lassi Lethglinni oc légund i fail Mo } \\
\text { Lasse }\end{array}$ & 5 & $\mathrm{~F}$ & $\mathrm{~F}$ \\
\hline 9 & Caillech dorat a mac dósum do Mling & 5 & $(F ?)$ & $\mathrm{F}$ \\
\hline 9 & Cath Carn Chonaill & 5 & $\mathrm{~F}$ & $\mathrm{~F}$ \\
\hline
\end{tabular}


Table 5 (continued)

\begin{tabular}{|c|c|c|c|c|}
\hline $\begin{array}{l}\text { Cluster } \\
\text { ID }\end{array}$ & Title & Volume & $\begin{array}{l}\text { Scribe } \\
\text { (Schlüter) }\end{array}$ & $\begin{array}{l}\text { Scribe } \\
\text { (Duncan) }\end{array}$ \\
\hline 9 & Cath Maige Mucrima & 5 & $F(+S)$ & $\mathrm{F}+\mathrm{S}$ \\
\hline 9 & Cethrur macclerech & 5 & $\mathrm{~F}$ & $\mathrm{~F}$ \\
\hline 9 & Cogad Gaedel re Gallaib & 5 & $\mathrm{~T}$ & $\mathrm{~T} 2$ \\
\hline 9 & Cormac mac Cuilennain cecinit & 6 & $\mathrm{~T}$ & $\mathrm{~T} 1$ \\
\hline 9 & Cummíne Fota mac Fiachnai di Eoganacht Chassil & 5 & A & $\mathrm{F}$ \\
\hline 9 & $\begin{array}{l}\text { Cóica epscop dodeochatar dochum Moedoc Ferna } \\
\text { do Bretnaib Cille Muine }\end{array}$ & 5 & $\mathrm{~F}$ & $\mathrm{~F}$ \\
\hline 9 & De Chophur in da Muccida & 5 & $\mathrm{~F}$ & $\mathrm{~F}$ \\
\hline 9 & Dindgnai Temrach & 1 & $\mathrm{~T}$ & $\mathrm{~T} 1$ \\
\hline 9 & Do fallsigud Tána Bó Cualnge & 5 & $\mathrm{~F}$ & $\mathrm{~F}$ \\
\hline 9 & Drochcomaithech ro baí i n-ocus dosom & 5 & $(F ?)$ & $\mathrm{F}$ \\
\hline 9 & Epscop do Gaedelaib dochoid do Róim & 5 & $\mathrm{~F}$ & $\mathrm{~F}$ \\
\hline 9 & $\begin{array}{l}\text { Fechtas do Mling is Tóidin co n-acca Mael } \\
\text { Doborchon }\end{array}$ & 5 & $(F ?)$ & $\mathrm{F}$ \\
\hline 9 & Fechtas dósom oc ernaigthi ina eclais & 5 & $(F ?)$ & $\mathrm{F}$ \\
\hline 9 & Fland Manistrech Cia triallaid nech aisnis & 4 & $U$ & $\mathrm{U}$ \\
\hline 9 & Fothart for trebaib Con Corbb & 1 & $A(?)$ & A \\
\hline 9 & Gormlaith ingen Flain cia dír do chlérchib na cell & 1 & A & A \\
\hline 9 & $\begin{array}{l}\text { Gormlaith ingen Flain tanic ar debaid ó Cherball } \\
\text { mac Murician }\end{array}$ & 1 & $A+T+2$ & $\mathrm{~T} 2$ \\
\hline 9 & lartaige na hingine colaige do Grécaib & 5 & $\mathrm{~F}$ & $\mathrm{~F}$ \\
\hline 9 & Immacallam in dá Thúarad & 4 & $\mathrm{U}$ & $U$ \\
\hline 9 & Incipit Cath Ruis na Ríg & 4 & A & A \\
\hline 9 & Incipit de maccaib Conaire & 5 & $\mathrm{~S}$ & $\mathrm{~S}$ \\
\hline 9 & Longes Chonaill Chuirc & 5 & $\mathrm{~F}$ & $\mathrm{~F}$ \\
\hline 9 & Longes mac nUsnig & 5 & $U(+M)$ & $U(+M)$ \\
\hline 9 & $\begin{array}{l}\text { Luid Feidilmid Rechtaid ó Themair do sáerchuaird } \\
\text { for Laigniu }\end{array}$ & 1 & $A+T+2$ & T1 (over A) \\
\hline
\end{tabular}


Table 5 (continued)

\begin{tabular}{|c|c|c|c|c|}
\hline $\begin{array}{l}\text { Cluster } \\
\text { ID }\end{array}$ & Title & Volume & $\begin{array}{l}\text { Scribe } \\
\text { (Schlüter) }\end{array}$ & $\begin{array}{l}\text { Scribe } \\
\text { (Duncan) }\end{array}$ \\
\hline 9 & Luid Mael Ruain Tamlachta fechtas dia airge & 5 & $\mathrm{~F}$ & $\mathrm{~F}$ \\
\hline 9 & Medb Lethderg Macc Moga Corbb celas clú & 1 & A & A \\
\hline 9 & Mesca Ulad & 5 & M & M \\
\hline 9 & Na Trí Fothaid & 4 & A & A \\
\hline 9 & Noenden Ulad 7 Emuin Macha & 2 & U & U \\
\hline 9 & Orgain Dind Ríg & 5 & $\mathrm{~F}$ & $\mathrm{~F}$ \\
\hline 9 & Ri irissech ro boí do Grecaib & 5 & $\mathrm{~F}$ & $\mathrm{~F}$ \\
\hline 9 & Scél Niall Frossach & 5 & $F+A$ & A \\
\hline 9 & Scél mucci Meic Da Thó & 2 & $\mathrm{U}$ & $U$ \\
\hline 9 & Scéla Chonchobuir & 2 & $\mathrm{~F}$ & $\mathrm{~F}$ \\
\hline 9 & Senchas Ailiúin Chobthaig & 5 & $\mathrm{~F}$ & $\mathrm{~F}$ \\
\hline 9 & Sloiged már rucsat Gréic co Hebríb fechtas n-aile & 5 & $\mathrm{~F}$ & $\mathrm{~F}$ \\
\hline 9 & Story of Athirne Ailgessach and Midir of Brí Leith & 2 & U & $U$ \\
\hline 9 & $\begin{array}{l}\text { Story of Athirne and Amairgen son of Ecet Salach } \\
\text { and Aigidecht Aithirne }\end{array}$ & 2 & U & $U$ \\
\hline 9 & Talland Etair & 2 & U & $U$ \\
\hline 9 & Tech Midchúarda & 1 & $\mathrm{~T}$ & $\mathrm{~T} 1$ \\
\hline 9 & Temaile fáid Miled Espáin & 4 & A & A \\
\hline 9 & Tochmarc Ferbae & 5 & $\mathrm{U}$ & $\mathrm{U}$ \\
\hline 9 & Trefocul & 1 & $\mathrm{~T}$ & $\mathrm{~T} 2$ \\
\hline 9 & Triar macclerech & 5 & $\mathrm{~F}$ & $\mathrm{~F}$ \\
\hline 9 & Tréide Cétna Labratar larna Genemain & 2 & $\mathrm{U}$ & $\mathrm{U}$ \\
\hline 9 & Trí Dé Donand & 1 & $\mathrm{~T}$ & $\mathrm{~T} 1$ \\
\hline 9 & Táin Bó Fraích & 5 & $\mathrm{~F}$ & $\mathrm{~F}$ \\
\hline 9 & Túarastla Rosa Failgi & 1 & $A+T+2$ & A \\
\hline 9 & Fingal Ronain & 5 & $F(+A)$ & $\mathrm{F}$ \\
\hline 9 & Óenach Talten & 5 & $F+A$ & A \\
\hline
\end{tabular}


Acknowledgement: The author would like to thank Miles Gould, Miles Osborne, and the anonymous reviewers for their insightful and helpful comments on earlier drafts of this paper. All errors are, of course, the author's own. 
